\title{
Móczár József
}

\section{Pénzügyi válság, gazdaságpolitika és a közgazdaságtudomány (Nemegyensúlyi paradigma)}

\begin{abstract}
A 2007-2009-es pénzügyi válság kapcsán számos politikus, közgazdász, de más tudományág képviselői is feltették a kérdést: miért nem lehetett elkerülni a válságot, miért nem bizonyult sikeresnek a közgazdaságtudomány a megelözésében? E cikk az eddigiektöl eltérően új választ ad e kérdésekre. Fö érve, hogy a gyakorlati gazdaságpolitika zsákutcába jutott, amikor a közgazdászok hosszú időre elfogadták a hatékony piac elméletén alapuló egyensúlyi modelleket. A múlt század közepén megjelent statikus egyensúlyi paradigma oly erősen uralkodik mind a mai napig, hogy sem Kornai (1971), sem Benassy (1982), sőt Goodwin (1991) intelmeit sem vették komolyan. A gazdaság ugyanis szinte sohasincs egyensúlyban, így "egyenletrendszereik" semmilyen útmutatást sem adhatnak a politikusoknak, hogy mit is kellene tenniük a felerösödött válságok idején. A Dornbusch-modell (1976) vagy Krugman-Obstfeld (2000) tankönyvi magyarázatai is pénzpiaciegyensúlyi helyzetből indulnak ki, és csakegy másikegyensúlyi helyzetbe történő átmenet mechanikáját írja le kis nyitott gazdaságokban. A szerző legújabb könyve (Móczár 2008) egy új paradigmához, a nemegyensúlyi modellezéshez nyit utat, aminek fel kell váltania az ortodox egyensúlyi paradigmát, hogy kezelni tudjuk a buborékokat, hogy megengedjük a pénzpiacok szabályozását stb. Itt most felvázoljuk ennek szükségességét.
\end{abstract}

Journal of Economic Literature (JEL) kód: E00, E5, E6, G28

Kulcsszavak: pénzügyi válság, hatékony pénzpiac, makroökonómia, monetáris és fiskális politika, gazdaság-matematika, pénzügy-matematika

A múlt században a közgazdászok két jelentősebb módszertani újítással próbálták segíteni a gazdaságpolitikusokat döntéseikben. Mindkettőt fájdalmas krízisek váltották ki, és mindkettő vitathatóan javította az állami beavatkozás hatékonyságát a gazdaságok irányításában. Az elsőt a nagy válság váltotta ki, amikor a közgazdászok megfogalmazták az első matematikai modelleket, többek között a keynesi elméleten alapuló modelleket, majd az általános egyensúly neoklasszikus modelljét is. A Ramsey-modell és annak CassKoopmans-féle átirata háttérbe szorult, a statikus egyensúly időbeli kiterjesztése jelentette a dinamikus egyensúlyt. Gyakorlati alkalmazhatóságuk azonban fel sem merülhetett, hiszen a II. világháborút követő újjáépítési periódusban, föleg az 1950-es és 60-as években, szinte valamennyi gazdaság növekedett, nem volt jelentős munkanélküliség és infláció stb. Mivel ezek többsége az egyensúlyi növekedést modellezte (az ún. turnpikokat), a 
gazdaságpolitikusok döntéseiket megalapozottnak tekintették a közgazdasági elmélet részéről is. A második az 1970-es infláció után következett be, amikor a közgazdászok olyan új modelleket fogalmaztak meg, amelyek figyelembe vették az emberek várakozásait is, az árakról és a jövedelemről, amelyek befolyásolhatják a gazdaság müködését hosszú távon. Sokan e modellek felhasználásának tulajdonítják, hogy az amerikai gazdaság a stabilitás és az alacsony infláció periódusába lépett, amely tartott az 1980-as évektől egészen a 2000-es évekig, ami sok közgazdásszal elhitette, hogy úrrá lettek az üzleti ciklusokon. A Chicagói Egyetemről Robert Lucas, e modellek egyik szellemi vezére, 2003-ban kijelentette: „(...) a depresszió központi problémáját megoldottuk (...) sok évtizedre."

Az eredmény az az új ortodoxia lett, ami „racionális várakozások” néven vált ismertté és beépült az egyensúlyi modellekbe, ezzel részben dinamizálva is. Lényegében még mindig ezek a közelítések dominálnak, alapul szolgálva mindennek, a nyugdíjalapok befektetésétől a pénzügyi elemzők értékpapír-értékeléséig. A legfőbb uralkodó nézet, hogy a piacok "hatékonyak", ami azt jelenti, hogy még egy kellő információval nem rendelkező befektető is megbízhat a piacban, mivel elméletileg bármely értékpapír ára az összes olyan lehetséges információt tükrözi, ami releváns az értékével kapcsolatban.

A 2000-es évektől azonban többen is erősen kételkedtek ebben, amit csak megerősítettek a Wall Streeten tapasztaltak, ahol egyre láthatóbban komoly pénzpiaci korlátok léptek fel. Ugyanis egy idő után nem volt elég ingatlan és más fedezeti forma a hatalmas adósságértékpapírok mögött, amit a bankárok deriváltak és még szerettek volna deriválni. Igy amikor a befektetők újabb „követelés-támogatott” értékpapírt kerestek, a bankároknak meg kellett találni a módját, hogy „kibővítsék” a lehetséges fedezet-kínálatot. Egyik találmányuk az volt, hogy a fedezetet kettős rendeltetésüvé tették. Például, a jelzálogkölcsönöket a bankok kettős rendeltetésűvé tették a komplex adósság-értékpapírokra, ami fedezett jelzálogkötelezettségként ismert. Egy másik volt, hogy többet kölcsönöztek a fedezetnél. Például, ha a bank csökkentette a foglalót egy 100000 dolláros házra 20\%-ról 5\%-ra, akkor 95000 dollárra kaphatott hitelt 80000 helyett. A bankok hasonlóképpen csökkenthették az elöleget vagy a margint, amit azoktól a befektetőktől kértek, akik a kölcsönzött pénzt kötvények vagy más értékpapírok vásárlására fordították.

Érdekes lehet itt megemlíteni, hogy a fedezet-kínálat bővítésében számos amerikai bank elég furcsa müveleteket is bevetett: a készpénzért kivásárolt életbiztosítások fedezetével értékpapírokat bocsátanak ki, amelyek tulajdonosai annál nagyobb hozamhoz jutnak, minél előbb halnak meg a biztosítottak.

A fentiekből eredő buborékokat és kipukkanásukat a következőképpen összegezhetjük: amikor a bankok nagyon alacsonyra teszik a margint, a fedezeti érték nagyságánál sokkal többet kölcsönözhetnek, s ezzel jelentösen befolyásolhatnak egy speciális befektetöcsoportot. Ezek többnyire kockázatitöke-befektetési alapok (hedge-fundok), vagy aspiráns otthontulajdonosok, akik különböző okok miatt magasabbra értékelnek egy adott típusú fedezetet. Az ily módon kölcsönzött hatalmas pénzösszeget felhasználva, ezek a vásárlók az árakat extrém szintekre nyomják fel. Mivel azok az árak messze felette vannak annak, ami elfogadható lenne, ezért a befektetők kevesebb kölcsönzött pénzt használnak, s ezzel megsértik a hatékony piacok elméletét. De ha egy váratlan rossz hír elbizonytalanítja a kölcsönadókat a közeli jövőről, azok megemelik a margint, ezzel eladásra késztetik a tőkepiaci eszközökkel ellátott optimistákat. Az beindít egy spirált lefelé: a csökkenő árak és az emelkedő marginok egymást erősítik. A bankok megfojtják a gazdaságot, mivel ilyen körülmények között óvatosabban kölcsönöznek. A pénzhiány viszont pénzügyi válsághoz vezet. 
A politikusok évtizedekig azt gondolták, hogy hitelpiacokon a kereslet és kínálat legfontosabb indikátora a kamatláb. Ez az egyetlen változó, amit igazítaniuk kell, hogy elérjék a kívánt gazdasági eredményt. Most viszont úgy tűnik, hogy a kölcsönzők fedezete vagy marginja még fontosabb lehet.

A Fed hivatalnokai is tapogatózva más alternatívák után kutatnak. A buborékok megelőzésének két módszeréből - szabályzók használata, hogy megvédjék a pénzügyi rendszert a feleslegtől és a monetáris politika megváltoztatása a kamatlábak emelésével - Bernanke választása a nagyobb szabályozásra esik, arra az elméletre, amit a múltban is hirdetett. Ezzel szemben a „kamatláb-kártyával történő játék” sokak szerint agresszívabb és kockázatosabb mozgást eredményez, és egy nagyon nyers eszköz a lehetséges buborék meghiúsítására. A kamatlábak emelése ugyanis egyidejúleg befolyásolhatja az összes többi tőkepiaci eszközárat is. Ezzel együtt a vita nem csendesült el teljesen, hogy vajon a kamatlábak képesek-e összenyomni a buborékokat. Ma (2010 első negyedévében, amikor e cikk született) a Fed véleménye az, hogy a kamatlábakat még több hónapig alacsony szinten kell tartani, hogy a gazdaság növekedésbe lendüljön át.

A jószágpiacokon és a feltörekvő gazdaságokban lehetséges újabb buborékoktól való félelem közepette, egyre nagyobb figyelmet kap az a kérdés, hogy vajon lehet-e és hogyan lehet megbirkózni a buborékokkal, mielőtt kipukkannának. Az arany ára több mint 50\%kal emelkedett az utóbbi egy évben. Kínában a sanghaji összetett részvényindex közel 80\%kal emelkedett 2009-ben. Brazíliában még jobban. Az olajárak visszaestek, az elmúlt évi csúcs alatt maradtak jóval, de ha visszatérnek a magasabb árak, inflációt gerjeszthetnek a jószágok és a szolgáltatások piacán, sokkal közvetlenebbül, mint tették a technológiai részvények vagy az ingatlanok esetében. 1999-ben a Fed-hivatalnokok Jackson Hole-ban tartott éves „konklávéjukon”, Bernanke és szerzőtársa, Mark Gertler óvtak a buborékok kiszúrásától, és úgy érveltek, hogy a Fednek az infláció ellenőrzésére kell koncentrálnia, és nem kell megkísérelnie a fellendülések és visszaesések ciklusait menedzselni. Greenspan egyetértett velük, és hagyta, hogy a technológiai buborékok a maguk útját járják. A stratégia győztesnek látszott. A 2001-es recesszió enyhe volt, a munkanélküliségi ráta sohasem haladta meg a 6,3\%-ot. A GDP csak 0,3\%-kal esett vissza a 2000. év negyedik negyedévéhez képest.

Sokan persze kételkedtek e stratégiában: a hitelcsődöt megelőzte az amerikai értékpapírforgalmazók, mint a Lehman Brothers vagy a Bear Stearns rövid távú kölcsönzéseinek robbanásszerü növekedése. Például, a repo-piacon folyó kölcsönzés, ahol a Wall Street-i cégek az értékpapírokat fedezetül használják a rövid távú kölcsönökre, 2002-ben az 500 milliárd dollárról megtriplázódott 1,6 trillió dollárra. Ahogyan emelkedett az értékpapírok értéke, úgy emelkedett a fedezeti érték és a cégek saját nettó értéke is. Ez arra sarkallta a cégeket, hogy még többet kölcsönözzenek egy öntápláló ciklusban. Amikor az értékpapírok értéke elkezdett esni, a ciklus megfordult, amit a gazdaság sínylett meg. A tanulság, hogy egy buborék legveszélyesebb része nem a tökepiaci eszközárak emelkedése, hanem az adósságszint, ami felerősíti a folyamatokat a pénzügyi intézetekben, és még magasabb árakat gerjeszt. Ebben az egyik legfőbb probléma az, hogy a közgazdászoknak nincs olyan modelljük, amely leírná, mennyivel kell emelni a kamatlábakat ahhoz, hogy megállítsák a következö buborékot, amikor a tőkepiaci eszközárak, vagy pusztán csak a pénzügyi eszközök többletre futnak.

Az USA-ban több ezer amerikai tüntetett a közelmúltban, hogy töröljék el a központi bankot, és helyettesítsék a Fed-et egy olyan pénzrendszerrel, amelynek ismét az arany vagy 
más jószág a fedezete. A tüntetők szilárd meggyőződése, hogy az a pénzkibocsátás, ahogyan a Fed teszi, alkotmányellenes. A beválthatatlan papírpénzt „fiat money”-nak nevezik, mivel nincs fedezete, ráadásul fenyegeti is a civilizációt azzal, hogy segíti a kormányokat a háborúk finanszírozásában, és alapot szolgáltat a pénzügyi kríziseknek. A Fed mérlegének hatalmas növekedését várják a krízis alatt, aminek következtében hanyatlásra és burjánzó inflációra számítanak, annak ellenére is, hogy a központi bankhivatalnokok váltig bizonygatják, ki tudják vonni a felesleges pénzt a piacról, amikor ott lesz az ideje.

Vajon milyen hatással voltak és lehetnek a közgazdaság-tudomány elméletei a válság leküzdésében és vica versa, továbbá milyen gazdaságpolitikát követnek ezek tükrében az USA-ban, illetve az EU-ban? Ezt vizsgáljuk a következő fejezetpontokban.

\section{A közgazdaság-tudomány amerikai és európai gazdaságpolitikai szerepe a 2007-2009-es válság tükrében}

A 2007-ben kirobbant válság kezelésére Csaba László (2008) azt írja könyvében: „a közgazdasági szakma jelenleg nem rendelkezik használható eszközökkel”. Szerinte egy vadonatúj elemzési eszközre van szükség, és szakítani kell az elmúlt 150 év tradíciójával. Amennyiben itt a neoklasszikus iskolára gondolt, valóban érdemes elgondolkodnunk javaslatán. Kiindulópontja az a sokunk, többek között Blanchard (2000:37) által is hangoztatott megállapítása, hogy „,a makro-ökonómia ma szilárdan az általános egyensúlyelmélet struktúrájára alapozott". Még a legújabb sztochasztikus dinamikus általános egyensúlyi (DSGE) modellek is (lásd Móczár 2008). Arra az elméletre, amit Kornai (1971) oly hevesen bírált az árufeleslegekre, illetve -hiányokra vonatkozó empirikus megfigyelései alapján, és ami a legújabb nemegyensúlyi kutatások szerint jogosnak is bizonyult (lásd Móczár 2006). Közismert, hogy az általános egyensúlyelmélet a newtoni fizikában, illetve annak matematikai kvadratúrájában, a differenciálszámításban gyökerezik, ami úgy értendő, hogy az egyensúlyi modell valamely dinamikai rendszer egyensúlyi állapotát írja le, vagyis mindenképpen statikus. Másképpen, az egyensúlyi modellek egyszerü lineáris vagy nemlineáris egyenletrendszerek, amelyek szinte sohasem fejeznek ki valós állapotokat, különösen nem a gyorsan változó világunkban, amit Goodwin (1991) oly élesen kritizált. Ahhoz, hogy e megközelítésen túllépjen, a közgazdasági elmélet új, feltehetően természettudományos közelítésű eredményeire lesz szüksége. Erre már a közelmúltban is voltak kísérletek, elég, ha csak Neumann János játékelméletére gondolunk, ami megszabadította a közgazdaságtant a differenciálszámítás kizárólagos alkalmazásától, ugyanakkor tovább mélyítette a statikus szemléletet.

A továbbiak kedvéért érdemes hangsúlyoznunk, hogy Csaba elméleti vizsgálataiban explicite a neoklasszikus iskola keretei között maradt. A közgazdasági Nobel-díjas Paul Krugman azonban szélesebb összefüggésbe és az amerikai akadémiai elméleti viták középpontjába helyezte a válság kérdését a The New York Times hasábjain 2009. szeptember 2-án megjelent írásával. Mivel a mostani pénzügyi, majd gazdasági világválság a legnagyobbnak tekinthető az 1929-1932-es Great Depression után, sőt egyesek, például J. B. Delong szerint a pénzügyi szektort jóval nagyobb sokkhatás érte most, nem tesz mást, mint egyszerủen arra emlékeztet bennünket, hogy hogyan sikerült akkor leküzdeni a válságot, ami egészen a II. világháborúig tartott, $\mathrm{s}$ ebben nyilván az állami hadiipari megrendelések is jelentős szerepet játszottak. Mindenki előtt ismert, hogy John Maynard Keynes elmélete 
világított rá a válság kialakulásának okaira a „The Great Slump of 1930” c. tanulmányában, és adott megoldást is a depressziók elkerülésére a jövőben. Keynes „legfőbb büne” az volt, hogy aktív állami beavatkozást sürgetett a munkanélküliség leküzdésére, mégpedig nagyobb pénzemisszióval, és ha szükséges, több állami kiadással. (Ez ma leginkább Soros György nézetével vág egybe.) Krugman szerint, bármennyire is paradoxonként hangzik, ezzel inkább erősíteni akarta a kapitalizmust, mintsem helyettesíteni mással. Viszont megkérdőjelezte azt az elképzelést, hogy a szabadpiaci gazdaságok magukra hagyhatók felügyelet nélkül, kifejezve ezzel a különös nemtetszését a pénzügyi piacokat illetően, amelyeken szerinte rövid távú spekulációk dominálnak kevés tekintettel a pénzügyi alapokra.

Krugman arra is rávilágít e cikkében, hogy az emberiség, most éppen a közgazdászok, nem tanul a saját korábbi hibájából. A „nagy válság”-ig a legtöbb közgazdász ragaszkodott azon víziójához, hogy a kapitalizmus egy tökéletes, vagy majdnem tökéletes rendszer. A hatalmas munkanélküliséget látván ez a vízió ugyan nem volt fenntartható, de amint a Great Depression emlékei feledésbe merültek, a közgazdászok visszatértek a régi ideálhoz, a neoklasszikus közgazdaságtanhoz, s ezzel egy olyan gazdasághoz, amelyben a racionális gazdasági szereplők együttműködnek a tökéletes piacokon, amit most különféle egyenletekkel írnak le. Vakon elfogadva ezt, „,a legtöbb közgazdász semmibe vette az emberi racionalitás korlátait, amelyek gyakran eredményeznek buborékokat és kipukkanásokat; problémás intézményeket, amelyek ámokfutáshoz vezetnek; a piacok, különösen a pénzügyi piacok tökéletlenségeit, amelyek a gazdaság operációs rendszerének hirtelen és elöre jelezhetetlen összeomlását okozzák; és végül a kreált veszélyeket, amikor a szabályozók sem hisznek a szabályozásban".

A neoklasszikus megújulást és a Keynes elleni támadást Milton Friedman kezdeményezte elsőként 1953-ban, mégpedig azon kijelentésével, hogy a neoklasszikus közgazdaságtan elég jól leírja a gazdaság tényleges működését ahhoz, hogy „felettébb gyümölcsöző legyen, és hogy több bizalmat kapjon". Monetarista doktrínája elvben egyetértett azzal, hogy a piacgazdaságnak nem autonóm stabilizációra van szüksége. De ez alatt csak annyit értett, hogy az állami beavatkozásnak egy nagyon korlátozott, körülírt formája az, ami szükséges a depressziók megelőzéséhez. Nevezetesen, utasítani a központi bankokat, hogy a nemzet pénzkínálatát, a forgalomban levő készpénzmennyiséget és a banki betéteket hosszú távú egyensúlyi pályán tartsák. Míg Adam Smith 1776-ban kiadott The Wealth of Nations c. kötetét követően kb. a 19. századig „bízz a piacban” volt a klasszikus közgazdaságtan üzenete, addig az azt követő neoklasszikus iskola az amerikai akadémiai életben „hinned kell a piaci rendszerben" tanításra cserélte fel. Míg az előbbi fenntartotta a piaci kudarcok lehetőségét, addig az utóbbi imperativusként hangzott, vagyis bármi történjék is, a piaci rendszer szent és sérthetetlen. S ezek a viták és a sokszor kőbe vésett üzenetek már az amerikai földrészen zajlanak és csontosodnak meg.

$\mathrm{Az}$ eddigi kutatások azonban csak a meglévő feltevések kis módosítgatásaival, átirataival próbálnak előbbre lépni (lásd Móczár 2008, 2009). Például, az új keynesi makroközgazdászok továbbra is hisznek az állam aktív szerepében, de legtöbbjük már elfogadja, hogy a fogyasztók és a beruházók döntéseikben racionálisak, és hogy a (pénz)piacok általában jól működnek. Maga Keynes azonban sohasem nézte jó szemmel a pénzpiacokat, mivel szerinte ott a spekuláción alapuló döntések dominálnak. „Amikor egy ország tőkenövekedése a kaszinó tevékenységének mellékterméke, a helyzet valószínüleg beteges." (Keynes 1936:142) 
Az 1970-esévektől Krugman szerint a pénzpiacok tanulmányozását Voltaire dr. Panglossának szelleme hatja át: vagyis, „mi élünk az összes lehetséges világ legjobbikában”. Az akadémiai életből eltűnt a befektető irracionalitása, a buborék, a romboló spekuláció tanulmányozása. Mindez ahhoz a paradox helyzethez vezetett, hogy a közgazdaság-tudomány

egyik gyökere, az erkölcs mint olyan, elhalt és teljesen kikerült a gazdasági folyamatok elemzéséből. A kutatásokat a „hatékony piac” hipotézise dominálta, ami a 80 -as évekre azt eredményezte, hogy a pénzügyes közgazdászok többsége elhitte, a nemzet tőkenövekedését a „kaszinó" tevékenysége határozza meg. A felfújt pénzügyi szektor odáig terjeszkedett, hogy a vállalati profitok 40\%-a ott keletkezett. Ebből az állapotból sokuk még a közbülső jeleket sem voltak hajlandók tudomásul venni! Például, 1973-74-ben a New York-i tőzsdén a részvények értékükből 48\%-ot vesztettek, 1987-ben pedig a Dow Jones-mutató 23\%-ot esett egy nap alatt.

A tőkepiaci eszközárazó (CAPM - capital asset-pricing model) és más befektetésárazó modellek megmutatják, a befektetőket hogyan jutalmazzák a rendszeres kockázatvállalásukért, feltéve, hogy valamennyi befektető racionálisan egyensúlyozza ki a kockázatot a hozammal szemben. A modellt Markowitz (1952) tanulmánya eredményezte, majd Tobin (1958) tanulmányát követöen Sharpe (1964) és Lintner (1965) fektették le a modell alapjait. A CAPM nemcsak azt mondja meg, hogyan állítsd össze a portfóliódat. Ennél sokkal fontosabb kérdést is megválaszol, mégpedig a pénzszektor szempontjából: azt is megmondja, hogyan árazzuk be a pénzderivatívákat, és állapítsunk meg követeléseket követelésekre.

Krugman (2009) világosan rámutat, a pénzügyes közgazdászok azért fogadták el a hatékony piac elméletét, mert a bizonyíték furcsán korlátozott volt. Ugyanis nem arra kaptak bizonyítékot, hogy vajon az aktívaárak értelmet kapnak-e a valós világ fundamentumai, mint például a keresetek mellett. Ehelyett csak azt kérdezték, vajon az aktívaárak értelmet kapnak-e más aktívaárak mellett. Persze az éles kritika nem maradt el: Larry Summers (1985) egyenesen „ketchup közgazdászoknak” nevezte a pénzügyeseket, akik szerinte feltevéseik mellett semmivel sem mutattak meg többet annál, mint hogy két kvart üveg ketchup változatlanul pontosan kétszer annyiért adható el, mint egy kvart üveg ketchup, és ebből következtettek a ketchuppiac tökéletes hatékonyságára.

Valóban nem lehetett látni előre a mostani válságot? A külső szemlélő erősen kételkedik; inkább azt látja, hogy az amerikai közgazdász szakma is erősen kettéválik az elmélet és a gyakorlat törésvonalán. Az előbbiek a tényekre szorítkozva, a valóságban érzékelhető folyamatokra terjesztik ki vizsgálataikat, míg az utóbbiak tevékenységét erőteljesen befolyásolják a gazdaságpolitikai megszorítások is, sok esetben a saját döntéseik igazolódását várják az események jobbra fordulásában, ezért sokszor jóhiszemüen nem akarnak tudomásul venni bizonyos baljós jeleket. Az előbbi esetre Krugman a Chicagói Egyetemről Raghuram Rajan professzor előadását emeli ki, aki már jóval korábban figyelmeztette a szakmát, a pénzügyi rendszer potenciálisan a kockázat veszélyes szintjén van. Az utóbbira pedig maga Greenspan, a Fed korábbi elnökének kijelentése szolgál példaként, amikor múlt évben elismerte, a válság kezdetén a „sokkolt hitetlenség” állapotában volt, mivel már akkor látta, hogy az „egész intellektuális épület összeomlott”. Az eredmény persze nem maradt el, és nem is fordult jobbra: az 1929-32-es válság óta a legnagyobb pénzügyi depresszió következett be az USA-ban, ami a dominó-elv alapján átterjedt az egész világgazdaságra és gazdasági válsággá terebélyesedett ki. Vajon felelőssé tehető-e Greenspan a válságért? Nem hiszem, még akkor sem, ha a pénzpiaci változók a gyorsabb állapotváltozók közé 
sorolhatók a modellekben. A piac visszajelzése ugyanis nem azonnal jut el a hatósághoz, s mire az megtalálja a megfelelő intézkedést, a katasztrófa pillanatok alatt bekövetkezhet, amit semmilyen pénzügyi modell nem képes elöre jelezni. Ez az eset is azt mutatja, hogy az elmélet és gyakorlat ritkán ér össze: Greenspan csípőbőlérzi az amerikai pénzpiac mozgását, csakúgy, mint Soros György a nemzetközi befektetési piacokét, annak ellenére, hogy „nem egyenletrendszerekben gondolkodnak”, s nem „értik a hatékony piac” elméletét sem. Nem is kell érteniük, mivel a valóságot nem hipotézisek alapján vizsgálják. Nyilván Eugene Fama elmélete hibátlan a feltevései mellett, de következtetései csak akkor helytállóak, ha azok a valóságban is megjelennek. S mindannyian tudjuk, hogy ennek nagyon piciny a valószínűsége.

Viszont Greenspant (2008) a legújabb írása olyannak mutatja be, aki képes reális képet is festeni a válság kialakulásának okairól. Az idézett cikkben ugyanis Greenspan elismeri „a relevencia és az elegancia közötti trade-off” alapján, hogy a modellek eleganciája mindenkit megtévesztett, és nem vették észre, hogy a piaci szereplők komplex és gyakran ellentmondó jelzéseit, legyen az pánik vagy eufória, túlságosan leegyszerüsítve foglalták magukban. Ezzel lényegében újrafogalmazta a szimmetria-tézis hiányát, és maga is megkérdőjelezte a racionalitás fogalmát, amit a modellkészítők kénytelenek voltak elfogadni az egyes technikák alkalmazhatósága kedvéért. Vagyis azzal, hogy felteszik, a piaci szereplők racionálisan viselkednek, ezzel teljesen kikapcsolják őket a további vizsgálatokból, de ezzel együtt ma már általános elfogadott vélemény a szakemberek körében, hogy a modellek jó elöre jelezték a kockázatokat.

Érdekes lehet itt megkérdezni, vajon a Blinder (1999) által sokat dicsért makroökonómia hogyan értelmezi a mostani válságot. Annyiban ugyan felmenthető, hogy Blinder elsősorban az üzleti ciklusok tanulmányozását tartja fontosnak a makro-ökonómia kutatásaiban, amelyek elsősorban a reálgazdaságra terjednek ki. Kiemeli az ún. „lehetetlen szentháromságot" is, amit Robert Mundell nevéhez kapcsolnak, és ami szerint egy nemzet a gazdasága reálfolyamatainak szabályozásában csak kettőt müködtethet a következő három gazdaságpolitikai eszközből: rögzített árfolyam, nemzetközitőke-mobilitás és független monetáris politika. Az utóbbi gyakorlása a Fed tevékenységi körébe tartozik, s mivel sokan éppen a Fedet hibáztatják a válságért, ezért úgy tủnik, hogy az elmúlt évtizedben az USAban az árfolyam rögzítése és a tőkemobilitás kapott nagyobb hangsúlyt a reálfolyamatok szabályozásában. Ebből az is következik, a jövőben a pénz szerepét sokkal többre kell értékelnünk egy egyszerü fátyolnál, Locke (1692) „mennyiségi pénz”-elméletének metaforájánál. A mostani válság kitünő bizonyítékot adott arra is, hogy a pénzkínálat növekedése rövidtávon igenis befolyásolja a kibocsátást, s nem tekinthető egyszerűen „olajnak a gépezetben”, vagyis ebben az esetben a pénz nem semleges, mint azt David Hume (1752) hirdette hosszú távú vizsgálatai alapján. Ezzel igazolást nyert Hayek (1941) intelme is, hogy a pénz szerepét nem kerülhetjük meg a gazdasági folyamatok vizsgálatában, sőt a derivatívák világában újra kell értékelni.

Krugman (2009) szerint a makro-ökonómia azért sem tudott hitelt érdemlően figyelmeztetni a pénzügyi válságra, mert amerikai professzorai kb. 40 éve két nagy csoportba váltak szét a keynesi gazdaságpolitika megítélését illetően: a „sósvizűekre” (az óceánparti egyetemeken kutatókra) és az „édesvizűekre” (a kontinens belsejében müködő egyetemi kutatókra). Az előbbieknek többé-kevésbé keynesi víziójuk van a recessziókról, míg az utóbbiak a keynesi víziót értelmetlennek tartják. 
$\mathrm{Az}$,édesvizüek” a neoklasszikus iskola elkötelezett hívei, vagyis elemzéseiket azon premisszák mellett folytatják, hogy a gazdasági szereplők és a piacok racionálisak. A kereslet-kínálat egyensúlya mindig elérhető, mivel az árak úgy mozognak, hogy drasztikus kereslet-hiány nem állhat elö, s ezzel, föleg a chicagói iskola hívei azt hirdetik, hogy a keynesi közgazdaságtan „hamisnak bizonyult”.

Hogy recessziók mégis bekövetkeznek, ezzel kapcsolatban a Nobel-díjas Lucas (1975, 1976, 1977) úgy érvelt, hogy azokat ideiglenes konfúziók okozták: a munkások és a vállalatok nem tudták megkülönböztetni az egymást követő infláció és defláció miatt az árszínvonalbeli változásokat a saját különös üzleti helyzetükben bekövetkezett változásoktól. (Bővebben lásd in Móczár 2008.) Edward Prescott, szintén Nobel-díjas közgazdász, pedig azzal magyarázta mindezt, hogy az üzleti ciklusokkal párosuló árfluktuációkkal és keresletingadozásokkal semmit sem tehetünk. Az üzleti ciklus ugyanis a tőke- és a munkaerö-állomány, valamint a technológiai haladás ütemében bekövetkező változásokat tükrözi, amelyek felerősödnek a munkások racionális válaszával: amikor a környezet számukra kedvezö, akkor szándékosan többet dolgoznak, mint amikor kedvezőtlen. Másképpen, bármely periódusban a ledolgozott órák száma, azaz a munkaerő-kínálat nemcsak a jelenlegi reálbérektől függ, hanem a várható jövőbeli reálbérektől is. Vagyis Prescott a munkanélküliséget a munkások szabad döntésével, Krugman iróniájában, a „vakáció kivételével” magyarázza, ami elég furcsán hangzik depresszió idején. Ennek ellenére, a Prescott elméletét premisszaként tartalmazó matematikai modell, amit Fin Kydlanddel együtt fogalmazott meg (Kydland-Prescott 1982), ma is számos egyetemen dominálja a makroökonómiát.

Amíg az „édesvizü” közgazdászok a tiszta elméletet képviselik, addig a „sósvizűek” egyértelműen pragmatisták. Mankiw, Blanchard és David Romer elismerték, hogy a keynesi keresleti oldalt nehéz összeegyeztetni a neoklasszikus elmélettel a recessziók tükrében, $s$ hajlandók eltávolodni a tökéletes piac vagy tökéletes racionalitás feltevéstől. Mindez azt is jelenti, hogy többé-kevésbé elfogadják a recessziók keynesi magyarázatát.

Krugman is felteszi a sokak által (még az angol királynő által is) feltett kérdést: nem lehetett volna előre jelezni ezt a válságot? És azonnal meg is válaszolja: néhány közgazdász megtette, de mivel a döntési pozíciókban levő politikusok nem tudták, vagy nem akarták látni pontosan a romboló következményei miatt, ezért „a szőnyeg alá söpörték” a figyelmeztető tanulmányokat vagy előadásokat. Így hiába figyelmeztetett Robert Shiller, amikor 2004ben Greenspan elutasította az ingatlanbuborékot azzal, hogy a legvalószínütlenebbnek minősítette, vagy 2005-ben, amikor Bernanke a lakásárak emelkedését úgy kommentálta, hogy az erös gazdasági fundametumokat tükröz.

Egyáltalán, hogyan lehetett nem tudomásul venni a buborékot, amikor a kamatlábak szokatlanul alacsonyak voltak, ami részben megmagyarázhatja az áremelkedést. Eugene Fama, a hatékony piac atyja, a következőképpen magyarázta ebben az esetben, hogy miért bízhatunk a hatékony piacban: „Az ingatlanpiacok a legkevésbé likvidek, de az emberek óvatosak, amikor házat vásárolnak. Tipikusan a legnagyobb beruházás, amit készülnek megtenni, ezért óvatosan körülnéznek és összehasonlítják az árakat. A szerződési folyamat nagyon részletes." (Idézi Krugman 2009.)

Érdekes itt megemlíteni, hogy Csaba (2009) nem sokat foglalkozik azzal a kérdéssel, hogy vajon lehetett-e látni elöre a pénzügyi, majd gazdasági válság bekövetkezését. Öt inkább az érdekli, hogy miért nem vették figyelembe a sokkal korábban megjelent figyelmeztetéseket a neoklasszikus iskola feltételrendszerének tarthatatlanságáról. Például, Herbert Simon már 1957-ben kísérletileg is bizonyította a korlátos racionalitási elmélet relevanciáját, amit 
Selten (1998) az emocionális viselkedésen túl minden emberi tevékenységre is kiterjesztett. Érdemes még kiemelni Frydman és Goldberg (2007), valamint John Eatwell (2007) intelmeit is, akik azért hibáztatják a közgazdasági kutatások természetét, mert kizárólagosan a mikro-ökonómiára fókuszálnak és megszállottan a „precíz” előre jelzésekre törekednek, ugyanakkor fontos információs forrásokat negligálnak.

Persze voltak ennél megrázóbb felfedezések is. Itt elég csak az 1970-es évek elején meg-született DSM-tételt citálnunk, ami valójában romba döntötte a neoklasszikus közgazdasági elmélet „mikro-megalapozási” kísérletét - vagyis, hogy az aggregált keresletet és kínálatot a hasznosságmaximalizáló piaci szereplők viselkedéseként írják le. Így lényegében hiábavalóknak bizonyultak azok a múlt század erőfeszítések, hogy az aggregált keresletet a hasznosságmaximalizálás eredményeként szerepeltessék. (Bővebben lásd Shafer-Sonnenschein 1982.) A neoklasszikus növekedés Ramsey-modellje is idejétmúlt: míg nála a célfunkcionálban a boldogság a maximális nettó hasznosságot jelentette, addig a legújabb kutatások nem a felhalmozott vagyon hasznosságával mérik a boldogságot, hanem az ún. flow-állapottal, aminek energiaszintjén a maximális boldogság a legnagyobb teljesítményekre tesz bennünket képessé. (Bővebben lásd Csíkszentmihályi 1997.) Stiglitz ennél is továbbmegy és egyenesen a neoklasszikus elmélet csődjéről beszél, amikor kétségbe vonja azt a tanítását, hogy minden egyes gazdasági szereplő javadalmazása a társadalmi hasznosságát tükrözi, pontosabban azt, amivel hozzájárul a társadalom gazdagságához. Szerinte, ha ez így lenne, akkor a bankárok „a szegények közkonyhái előtt állnának sorba”.

Ilyen helyzetben jogos a kérdés: egyáltalán, bízhatunk a gazdasági elörejelzésekben? Mennyire annullálják a tényeken alapuló elemzéseket az egyes gazdaságpolitikusok felelőtlen kijelentései? Ugyanakkor a különböző közgazdasági iskolák elméletei és különbözőségei mennyire akadályozzák a gazdaságpolitikusokat a helyes döntésekben? Valóban a Wall Street „pénzügyi büvészei” sodorták az összeomlás szélére a világot? Lehet-e bízni a jegybankokban, főleg a Fed monetáris politikájában?

Az egyetemi tankönyvek azt tanítják, hogy normál recesszió alatt a Fed kincstárjegyeket vásárol - rövid távú állami adósság - a bankoktól, ami csökkenti az államadósság kamatait; a beruházók magasabb megtérülési rátát keresnek, ezért más aktívákba fektetnek be, ami szintén a többi kamatláb csökkenéséhez vezet; és normálisan ezek az alacsonyabb kamatlábak végül egy gazdasági visszarendeződéshez vezetnek. A Fed az 1990-ben kezdődő recesszió kezeléséhez a rövid távú kamatlábakat levitte 9\%-ról 3\%-ra, a 2001-ben 6,5\%ról 1\%-ra és a mostani recesszióban 5,25\%-ról 0\%-ra. Hamarosan kiderült azonban, hogy zérus kamatláb sem elegendő a recesszió leküzdéséhez. Viszont a Fed nem viheti zérus alá a kamatlábakat, mivel a zérus-közeli rátákon a befektetők inkább felhalmozzák a készpénzt, mintsem kikölcsönzik. Ezért 2008 végére a recesszió oly mértékben elmélyült, hogy a konvencionális monetáris politika elveszítette az összes befolyását.

És pontosan ez az, amit Keynes felismert, hogy a kamatlábaknak is van egy alsó értéke, amelyen a monetáris politika megszünik müködni, és ez vezette őt a magasabb állami kiadáshoz: amikor a monetáris politika már nem hatékony és a magánszektor nem győzhető meg, hogy többet költsön, akkor a fiskális politikának kell helyébe lépnie, azaz az állami szektornak kell elősegítenie a kereslet növekedését a gazdaság talpra állításában. A fiskális ösztönzés a keynesi válasz olyan mély depresszió idején, mint a mostani is.

Ez a keynesi elmélet az alapja ma az Obama-adminisztráció gazdaságpolitikájának is; és az „édesvizűek” természetesen dühösek. Körülbelül 25 éven át tolerálták a Fed erőfeszítéseit, hogy menedzseljék a gazdaságot, de a keynesi elmélet leporolása és újra alkalmazása 
valami egészen különböző Friedmann monetáris politikájától. A chicagói Chocranet megbotránkoztatta az az elképzelés, hogy az állami kiadások enyhíthetik a legutóbbi válságot: „Az nem része annak, amit bárki is tanult egyetemi hallgatóként az 1960-as évek óta. Azok [a keynesi elméletek] tündérmesék, amelyek hamisnak bizonyultak. Feszültség idején nagyon kényelmes visszamenni a tündérmesékhez, amiket gyerekként hallgattunk, de az nem teszi őket kevésbé hamissá." (Idézi Krugman 2009.) Persze ennek ellenére olyan nagy múltú egyetemek, mint a Harvard, Princeton és az MIT tanítják Keynes elméletét. És tanítjuk mi is a Budapesti Corvinus Egyetemen, mégpedig Mankiw 2003/1997:25.) interpretációjában ${ }^{1}:$ „... könyvem integrálja a keynesi és a klasszikus közgazdaságtan eredményeit. A gazdasági ingadozások keynesi szemléletének elsődleges szerepe ebben a könyvben - és a legtöbb tankönyvben - Keynes Általános elméletének hatását és fontosságát igazolja. (...) elismerem, hogy a gazdasági ingadozások megértéséhez Keynes és az újkeynesiek sok gondolata nélkülözhetetlen."

Az EU monetáris politikája elemzésénél érdemes elidöznünk egy kicsivel többet is, úgy is, mint az euró bevezetésére aspiráló ország, és úgy is, mint elemző közgazdász. Csaba szerint, ha valamiért bírálható az euró, az, az, hogy túlságosan erős valuta. ${ }^{2}$ Az euró USAdollárban mért árfolyama a bevezetéskor 1,17 volt, ami 2001-ben 0,81-re gyengült, majd 2008 végére már 1,25-re erősödött, ma pedig már 1,5117. Ennek megfelelően a GDP nőtt: 2001-2005 között évi 1,5\%-kal, 2006-ban 2,8\%-kal, majd 2007-ben 2,7\%-kal. Viszont a munka-nélküliségi ráta csökkent: 8,5\%, 8,2\% és 7,4\%-kal ugyanezekben a periódusokban. A fizetési mérleg kicsi, de állandó többletet mutatott. Az ECB monetáris politikája biztosította az erős árstabilitást, a HICP értékei az előző periódusokban rendre 2,2\%, 2,2\% és 2,1\% volt.

Vajon milyen mértékben érintette magát az EU-t és intézményi válságát az USA-ból kiinduló pénzügyi válság? Milyen súlyt kapott ebben a periódusban az állami beavatkozás, illetve a monetáris politika? Azt hiszem, hogy azt senki sem vitatja, hogy a 2007-2009 közötti gazdasági világválságot az USA-ból kiinduló pénzügyi válság okozta. Az EU fejlődése, amit az előbbi makro-mutatók értékei is mutatnak, töretlen volt. Ezt pedig elsősorban az ECB által gyakorolt monetáris politika biztosította. Mi volt ebben az ECB titka? Általános vélemény az, hogy az ECB nem követett tisztán inflációs célkitűzéseket. Ehelyett a két tradicionálisan legsikeresebb központi bankot, a svájcit és a Bundesbankot követte. Vagyis monetáris politikájukban az infláció mellett a pénzkínálat/M3 mutatónak és a középtávú makro-ökonómiai helyzet átfogó értékelésének adtak nagyobb hangsúlyt. Ez azt is jelentette, hogy az ECB önálló monetáris politikát követett, vagyis nem másolta a Fedet, sem a Greenspan alatti években, amikor szuper alacsony volt a kamat, sem a pánikreakcióban, ami a 2007-2008-as pénzügyi válsághoz vezetett. Ugyanakkor, az infláció fellobbanása az euró-zónában rendkívüli óvatosságra intette az ECB-t, ami azt eredményezte, hogy nem hallották meg azokat a szirénhangokat, amelyek az iparból és a banki szférából jöttek, és a monetáris szigor mielőbbi enyhítését követelték. E diszkrecionális monetáris politika fallaciájának elkerülésével, a rövid távú üzleti érdekeket szolgálva, az ECB-nek valóban sikerült hozzájárulnia a stabil gazdasági környezethez, ami elősegítette a növekedést és a foglalkoztatás javulását az euró-zónában középtávon.

\footnotetext{
'Bár én személy szerint jobban örülnék egy magyar szerző tankönyvének, de ennek hiányában legalább a BurdaWyplos (2004) könyvnek, amely európai statisztikával és az EU-s országok gyakorlati intézkedéseivel vezeti be a hallgatókat a makroökonómia tudományába.

2 Megjegyzendö, hogy e megállapítás föleg a 2008-2009 időszakra értendö.
} 
A helyzet azonban sokkal árnyaltabb az egyes országok szintjén. Az euró ugyanis közös árfolyamot jelent a többi valutához képest, ami hátrányos helyzetet teremt az egyes külkereskedelmi deficitben szenvedő EMU-tagországoknak, ami végül súlyos munkanélküliséghez vezet. (Erre kitűnő példát szolgáltat Németország és Spanyolország: az előbbiben az elmúlt időszakban 175 millió dollár külkereskedelmi többlet mellett 8\%os, míg ugyanazon időszak alatt az utóbbiban 84 millió dollár deficit mellett 19\%-os volt a munkanélküliség.) Vagyis saját valuta és önálló monetáris politika hiányában nem csökkenthető az árfolyam egy versenyképesebb szintre, ami helyreállíthatná a külkereskedelmi egyensúlyt és növelhetné a foglalkoztatottságot. Persze vannak sokkal komplexebb eszközök is: vagy a reálbérek csökkentése, vagy a termelékenység növelése. Hasonló gondokat okozhat az ECB irányadó kamatlába is: alacsony foglalkoztatás esetén a közös kamatláb emelése ugyanis nemhogy csökkentené ezekben az országokban a munkanélküliséget, hanem pontosan tovább növeli. Jóllehet az euró-övezet egészének gazdasági érdekei igénylik a restriktív monetáris politikát, ami viszont nem minden tagországnak kedvező. Egyre több kérdést vet fel a közös monetáris politika és a tagországok saját fiskális politikája. Pontosan ezek az anomáliák azok, ami nagyon körültekintő döntést igényelnek az EMU-ba történő belépéskor, különösen a kis nyitott, s ezzel könnyen sebezhető gazdaságok esetében, így hazánkéban is. (Idehaza nem látni sem a jobboldal sem a baloldal részéről olyan hatástanulmányokat, amelyek a fenti anomáliák vizsgálatát céloznák meg. Nyilatkozó politikusaink többsége mintha csak az előnyös oldalát látnák az euró bevezetésének.) Brüsszel és a nemzetközi hitelminősítő szervezetek viszont rendkívül hektikusan ítélik meg az egyes EU-s tagországokat. Például Görögország az euró-zónához történő csatlakozáskor egyetlen kritériumnak sem tett eleget, és hasonlóan semmilyen hátrány sem érte Olaszországot a tőkepiacokon a közelmúltban, annak ellenére, hogy államadóssága a GDP-jének 104\%-a volt. Pontosan ők azok az országok, amelyeknek komoly gazdasági hátrányokat okoz a közös valuta és az alapkamat, amint azt a mostani nehézségeik is mutatják. De Nicholas Sarkozy is panaszkodik az erős euró miatt, mivel az komoly nehézségeket okoz a francia exportöröknek.

A keynesi elmélet „állami beavatkozás”-politikáját tekintik nagyon sokan az egyetlen hatékony eszköznek a válság kezelésében. A begyürüzött válság kezelésében még az államosításoktól sem riadnak vissza az egyes kormányok. Sőt J. B. Delong szerint a válság elkerülését lehetővé tette volna az amerikai Fannie Mae és a Freddie Mac ingatlanhitelezők államosítása, valamint a monetáris és a fiskális politika fókuszának az irányadó bankközi rátáról a jelzáloghitelek menedzselésére történő áthelyezése.

Tanulmányunk szempontjából rendkívül fontos kérdés, hogy akár egy Európai Egyesült Államok, akár csak egy szabad kereskedelmi zóna is mennyiben járul hozzá a (hazai) közgazdaságtudomány fejlődéséhez? Hazánkban eddig nincsenek jó tapasztalatok: a mostani IMF-hitel rendkívüli mértékben leszükítette a hazai fejlődéskutatások mozgásterét. Az illetékes gazdasági minisztériumok, ahol eddig szorgos kutatások folytak a hazai gazdaságfejlesztési elképzelésekre, lényegében csak az IMF-től kapott instrukciókat tanulmányozzák. Mondanunk sem kell, hogy hasonlóképpen szólhatunk a fiskális politikáról is. Az MNB is csak addig folytathat önálló monetáris politikát, amíg nem kapcsolódunk az euró-zónához. Utána viszont teljesen megváltozik funkciója, nyilván az ECB fiókjaként müködhet tovább, rendkívül korlátozott mozgástérrel. Vagyis a közgazdasági kutatásoknak is irányt kell váltaniuk, s kérdés, mivel rendkívül kis súlyt képviselünk az EU-ban, hogy kellőképpen fel tudunk-e erre készülni? 


\section{Matematikai modellek a közgazdaság-tudományban}

Itt abból érdemes kiindulni, hogy a meglévő matematikai modelleket általában kevésbé tekintik a mostani válság okaként. Ezzel szemben Krugman (2009) homlokegyenesen másképpen vélekedik, amikor úgy fogalmaz, hogy „(...) a közgazdasági szakma azért tért rossz útra, mert a közgazdászok egy csoportja félreértette a szépséget az igazsággal szemben, és az impresszív (tudományosnak tünő) matematikába burkolódzott. (...) A szakma kudarcának központi oka egy mindent átfogó, intellektuálisan elegáns közelítés utáni vágyakozás volt, ami lehetőséget adott a közgazdászoknak, hogy megmutassák a matematikai müveltségüket." Sokféleképpen értelmezhetők ezek a sorok, mindenesetre Krugmannak egy szempillantás alatt sikerült magára haragítania a matematikus közgazdászokat, különösen a pénzügyi matematikusokat, akik egyenesen támadásként vették cikkét a matematika közgazdaságtanban történő alkalmazása ellen. Olyannyira, hogy egy hétnél valamivel később Krugman (2009/a) kénytelen volt saját maga értelmezni sorait a békülés kedvéért. Nem hiszem, hogy rövid manifesztumával kielégítette volna bírálóit. Véleménye sem sokat változott, de most nagyobb hangsúlyt kapott nála, hogy „nem szabad a jó matematikát azonosítani a jó müködéssel: a CAPM mint modell csodálatos, de ez nem jelenti azt, hogy jól is müködik. Az üzleti reálciklus-modellek matematikája sokkal elegánsabb, mint az új-keynesi modelleké, nem is beszélve az olyan modellekröl, amelyek utat engednek olyan válságoknak, mint amiben most is vagyunk. Ez ugyan vonzóvá teszi az RBC-modelleket, de nem teszi őket semmivel sem kevésbé butácskákká." Annak bizonyítékaként, hogy kevés matematikával, vagy annak teljes mellőzésével is születhetnek nagyszerü közgazdasági munkák, Akerlof (1970) cikkére emlékeztet, amelyben virtuálisan nincs explicit matematika a fö kifejtésben, mégis elméletében transzformatív.

Tény, hogy mára már egyféle divat lett szidni vagy éppenséggel dicsérni a matematikai formalizmust. Sok matematikus minimális közgazdasági ismerettel, és hasonlóan, sok közgazdász még kevesebb matematikai háttérrel megpróbálja befogni vitorlájába a számára kedvező szeleket. Számos szerzőt idézhetünk a világ bármely részéből, akik sztereotip közelítésekkel próbálják alátámasztani igazukat. Mások, mint például Zalai (2000), nem bocsátkoznak vitába, egyszerüen idézik a múltat. És ez nagyon hosszú időre tekint vissza: akár Jevonsig vagy Marshallig is visszamehetünk. A múlt század első harmadában dőlt el a kérdés végérvényesen, akkor erősödött fel a matematika alkalmazása tudományunkban. A kor legfejlettebb matematikai kvadratúrája kétségtelen, hogy a differencia- és differenciálszámítás volt, tehát a newtoni fizika determinisztikus matematikája, és az akkori közgazdasági ismeretek mellett elismerésre méltó alkalmazásuk. Azóta több mint fél évszázad telt el, rengeteg kutatási eredménnyel és tapasztalattal, s ennek ellenére is csak nagyon kevesen jutnak el a lényegi kérdéshez: vajon a newtoni determinisztikus matematika az egyetlen megfelelő kvadratúra a közgazdasági modellezésben? Szerintem nem. Az nem lehet kétséges, hogy a mai bonyolultságában tudományunk jó néhány problémafelvetése csak logikai úton oldható meg. Tehát a matematika, csakúgy, mint a természettudományokban, jelen kell, hogy legyen, s még inkább igaz ez, ha elfogadjuk a közgazdaság-tudomány természet-tudományos közelítését. A pénzügy-matematika új irányokban keresgél, s kétségtelen, hogy technikai arzenálja közelebb visz bennünket a valóság jobb megismeréséhez. Paradox helyzet, hogy alapjaiban megmarad a newtoni matematikánál, amennyiben a kiindulási Langevin-féle differenciálegyenlet a newtoni egyenlet sztochasztikus változata, amiből ered az Ito-integrál, a sztochasztikus 
folyamatok stb. A reálgazdaság matematikai módszerekkel történő vizsgálatai (termelési függvények, programozási technikák, növekedési modellek, általános egyensúlyi modellek, tevékenységelemzés stb.), illetve az az irányzat, amit klasszikus matematikai közgazdaságtannak nevezhetünk, s föleg a Cowles-bizottság kutatási eredményeit foglalja magában, mára majdnemhogy a közgazdasági alapismeretek között szerepel. Weintraub (2002) könyve bármennyire is nagyszerü, de ő is leragad a matematikai közgazdaságtan klasszikus reálgazdasági értelmezésénél. A matematikai közgazdaságtan frontvonalában ma a pénzügy-matematika szerepel, ha úgy tetszik, ez a sláger, s a mai kidolgozottsága mellett, értem itt az eredeti cikkek kevésbé jó didaktikáját és stílusát, még nagyobb kihívást jelenthet a közgazdászok számára. De nem kerülhetők meg: az értékpapírpiacok és a hatóság közötti interakciók (Soros György fogalmazásában, reflexivitás) nélkülük nem érthetők meg. Következésképpen, ha az új generációk nem tanulnak kellő mélységben sztochasztikus dinamikát, az ellenzők tábora még nagyobb hangerővel adja tudtunkra nemtetszését a gyakorlati szférából. Az is világos, hogy ez nem is csendesedhet el, és ez így is van rendjén. Hiszen a gyakorlati közgazdaságtan és az elméleti közgazdaság-tudomány között mindig is lesz, és lennie is kell egy résnek: bármely tudományág elméleti művelésének ugyanis a gyakorlat előtt kell haladni. Csak nem szabad túl sok időt pazarolni ezekre a szirénhangokra, különösen nem a mester- és a doktori képzésben!

Mostanában sok közgazdász kölcsönzi Einstein intelmét, miszerint a makro-modelleknek olyan egyszerüeknek kell lenniük, amennyire csak lehetséges, és semmivel sem jobban. A ma használt modellek ezzel szemben rendkívül bonyolultak, többségük empirikus elemzésekre alkalmatlan.

A makro-ökonómiai modellezés az 1940-es és 1950-es években az empirikus elemzésen és a „trial and error” elvén, azaz a múlt gyakorlatán fejlődött. Az 1970-es években kezdték el tudományossá tenni részben a mikro-megalapozással, részben pedig az általános egyensúlyi keretben a racionális várakozások beépítésével, ami az új-klasszikus makro-ökonómiai modelleket eredményezte. A mikro-megalapozást a reprezentatív gazdasági szereplő (ágens) jelentette, ami lehetővé tette a DSM-probléma elkerülését. Ezzel viszont érdekes paradox helyzet állt elő: mivel a mikro-ökonómia feltevései az egyénekről introspekción alapulnak, ezért semmi sem lehet jobban ad hoc, mint maga a standard mikro-megalapozás. Vagyis a ma használt tudományos makro-modellek mindegyike ad hoc. Nem elég csak a reprezentatív szereplö magatartását figyelembe venni, hanem elemezni kell a modellben az interakcióik struktúráját és annak hatását is. Ennek hiánya a fó kritika a DSGEmodellekkel szemben is, amelyek alternatíváit az ún. heterogén ágens makro-modellekben látják, amelyek figyelembe veszik az ágensek közötti kommunikációt, a komplexitást, a koordinációs problémákat és az endogén tanulást.

Az új közelítésben a gazdasági szereplők (ágensek) nincsenek egyensúlyban a mikroökonómiai értelmezés szerint. Viszont a nem egyensúlyi állapotaik kiegyenlítik egymást, ami a mikro-dinamikát összekapcsolja a makro-egyensúllyal, és a heurisztikus és ad hoc ökonometriai modellek helyett a szofisztikáltabb statisztikai modellek felhasználását javasolja. Ilyen például a vektor autoregresszív modell. E modellek eltekintenek az oksági modellek, mint például a DSGE szigorú feltételeitől. De hogyan integráljuk a statisztikai eredményeket az elméletekbe? Az egyik válasz, hogy a DSGE-modelleket mint bayesi priorokat tekintsük. Egy másik, a kointegrált vektor autoregresszív modellezés, ami lehetővé teszi az elmélet és a statisztikai elemzés összekapcsolását. 


\section{Tanulságok}

Krugman szerint, ami most következik, az az, hogy a „flaws-and-frictions” közgazdaságtan a gazdasági elemzések perifériájáról a középpontjába fog elmozdulni. Az az iskola, amely „behavioral finance" néven ismert, és amely két dolgot hangsúlyoz: elöször, sok reálvilági befektető túlságosan is a csordaviselkedés, az irracionális kinövés és a váratlan pánik követője. Másodszor, még azok is, akik döntéseiket a hüvös számításra alapozzák, gyakran találják magukat olyan helyzetekben, hogy nem képesek arra, mivel a hit-, a bizalom- és a korlátproblémák arra kényszerítik őket, hogy a csordával együtt rohanjanak. A leginvenciózusabb tanulmány ebben az áramban Krugman szerint Andrei Shleifer (Harvard) és Robert Vishny (Chicago) publikációja volt 1997-ben, amelyben kimutatták, hogy az arbitrázsőröknek akik feltehetően alacsony áron vásárolnak, és magasabbon adnak el - szükségük van tőkére tevékenységük gyakorlásához. És egy komoly hazardírozás az aktíva árakban, még ha annak semmi értelme sem a fundamentumokban, csökkenteni fogja a tőkét. Eredményül, az okos pénz kiszorul a piacról, és az árak spirálisan lefelé zuhannak.

Csaba nem foglalkozik explicite a makro-ökonómia elméletével. Inkább az EU, illetve az újonnan csatlakozott országok felzárkózását és növekedését elősegítő kormányzati intézkedéseket sürget: kis vállalkozások támogatása, az oktatási rendszer fejlesztése, a nagy elosztórendszerek felülvizsgálata stb. Az alkotmányosság felülvizsgálatát sokkal szélesebb alapokra helyezi, mint a konvencionális politikatudomány, mégpedig a freiburgi iskola modern, Buchanan (1991) által megrajzolt alkotmányos politikai gazdaságtanára. Hayek (1978) politikai filozófiáját követi, amikor nagyobb alkotmányos hangsúlyt kíván helyezni a gazdasági rend elemeire, azaz, a makro-ökonómiai folyamatok és elemzések keretére.

Az elméleti kutatások terén „a merre tovább” típusú kérdésre adott válaszokban nem elhanyagolható, hogy a mostani események határozottan megcáfolták azt a tézist, miszerint a technológiai fejlődés ütemében bekövetkező fluktuációkra a recesszió az optimális válasz. Egy többé-kevésbé a mai modern gazdaságirányításához illeszkedő, a piac visszajelzéseit időben elemző állami gazdaságpolitika lehet a megfelelő válasz a válságok megelőzésére. Most is bebizonyosodott, hogy a pénzügyi piacok távolról sem tökéletesek, de egyáltalán nem biztos, hogy a keynesi elmélet követése lehet az egyedüli út a recessziók és a depressziók elkerülésében. Az viszont világos, hogy a pénzügyi realitásokat bele kell foglalni a makroökonómia elméletébe, modelljeibe, és olyan likviditásfokozó intézkedéseket kell hozni, amelyek a hagyományos monetáris politikai eszköztáron kívül állnak. Viszont ha továbbra is elfogadjuk a hatékony piac elméletét, és semmilyen módon sem szabályozzuk Soros György reflexivitás-elmélete alapján, akkor el kell fogadnunk Greenspan intelmét, hogy „sohasem lesz tökéletes kockázati modellünk” és a válságok ismét bekövetkezhetnek.

Hogy paradigmaváltásra van szükség, azt a Nobel-díj Bizottság legutóbbi döntése is bizonyítja, amikor a közgazdasági Nobel-díjat Elinor Ostromnak és Oliver Williamsonnak ítélte oda, amit azzal indokolt, hogy a mainstream közgazdaságtan túlságosan matematikaivá lett és egyre jobban eltávolodott a valóságtól. (Az indoklás utóbbi érvelésével egyetérthetünk, az előbbi már számos kérdést vet fel, amire most nem térünk ki.) A díjazottak azokat az intézményi struktúrákat vizsgálták, amelyek a valós világ problémáinak megoldását szolgálják, amelyek különböznek a szabad piacoktól, de nem állami intézmények. Williamson rámutatott, hogy a vállalatok közötti vertikális integráció növeli a piaci befolyást, míg a horizontális egyesülések csökkentik a költségeket és a nagyobb piaci befolyásuk növeli az árakat, ami több nyereséget hoz a gazdaságnak, mint 
veszteséget a fogyasztóknak. Ostrom Garett Hardin megfigyeléséből indult ki: amikor senki sem birtokol egy erőforrást, azt túlhasználják, mert senki sem ellenőrizheti használatát, és mindenki szándéka az, hogy előbb használja, mint a többi. Az emberi viselkedés e tulajdonsága vezetett arra a következtetésre, hogy jobb az erőforrásokat magántulajdonba adni állami ellenőrzéssel. Ostrom nem találta ezt egyértelmünek, és vizsgálatai során számos olyan közösségi tulajdont talált, amelyek müködtek, és olyanokat is, amelyek nem. A különbséget az okozta, hogy az elöbbiek egyféle tulajdonjog rendszerben müködtek, és pont nem magántulajdoniban. Ostrom számos szabályt javasolt a közös üzemeltetésű erőforrások menedzselésére.

A hitelbuborék olyan kérdések ismételt vizsgálatát kényszeríti ki, mint hogyan szelídítsük meg a bomlasztó fellendülést követő válságciklusokat. John Geanakoplos a Yale Egyetemről, szintén új gondolkodást ajánl a ciklusokról: a központról a határterületekre kell áthelyezni vizsgálatainkat. Nemcsak a kamatlábakra, hanem a kölcsönzött összeg nagyságára is nagyobb hangsúlyt helyez. A fellendülés idején szigorítják, hogy mennyi pénzt kölcsönözhetnek a különböző játékosok, a hedge fund-októl az otthonvásárlókig. Stiglitz szerint több lábon álló megoldás kell: speciális adók, több tőke-megfelelési mutató, szigorúbb felügyelet bevezetése, mégpedig a méretek és az engedélyezett kockázatvállalás korlátozása révén.

Az ECB a korlátlan likviditásnyújtást állította a válságkezelés fö eszközeként: tavaly májusban történelmi mélypontra, 1\%-ra nyomta le az irányadó kamatát, s 12 hónapra ezen annyi hitelt adott a hozzá forduló bankoknak, amennyit csak kértek. Decemberben viszont a kormányzótanácsi ülésen már bejelentették, hogy hamarosan vége a korlátlan likviditásnak. 2010 első féléve után lép életbe a szigorítás: az idei utolsó tenderlehetőséget kihasználó 224 banknak 1,05-1,25\% közötti kamattal kell számolnia a közel 97 milliárd eurónyi kölcsön után. A tendereken részt vevő bankok számának csökkenése megkönnyíti az ECB kivonulását a válságkezelésből, így ugyanis nem kell drasztikus eszközökkel lecsapolnia a piac esetleges túlzott likviditását.

A fenti intézkedések ellenére is, a pénzpiacokon várhatóan továbbra is óriási hangulati ingadozások lesznek, az eufóriát pánik váltja fel, s ezek a nagy amplitúdójú kilengések a pénzügyi liberalizáció miatt áttevődnek a reálgazdaságra is. Nyilván senki számára sem kell bizonyítani, hogy ilyen körülmények között az egyensúlyi modellek semmilyen támpontot sem adhatnak a gazdaságpolitikusok kezébe. Olyan új modellek kidolgozására van szükség, amelyek kezelni tudják a nem egyensúlyi helyzeteket, a hektikus változásokat, mégpedig annak beismerésével, hogy egyensúlyi helyzetek többnyire csak az elméletekben léteznek.

\section{Hivatkozások}

Akerlof, G. (1970): The Market for Lemons: Qualitative Uncertainty and the Market Mechanism, Quarterly Journal of Economics, vol. 84, August, 488-500.

Blanchard, O. (2000): What do we know about macroeconomics that Fisher and Wicksell did not know? De Economist, vol. 23. no. 3. 582-604.

Blinder, A. S. (1999): Economics becomes a science - or does it? In: A. Bearn (ed.), Useful Knowledge: The American Philosophical Society Millennium Program (Philadephia: American Philosophical Society).

Buchanan, J. (1991): Constitutional Economics, Oxford: Basil Blackwell.

Burda, M. and Wyplosz, Ch. (2005): Macroeconomics: A European Text, New York: Oxford University Press.

Csaba, 1. (2009): Crisis in Economics, Budapest: Akadémiai Kiadó. 
Csíkszentmihályi Mihály (1997): Flow - Az áramlat, Budapest, Akadémiai Kiadó.

Eatwell, J. (2007): Risk management and systematicrisk. In: Estrin, S., Kolodko, G. W. and Uvalic, M. eds.: Transition and Beyond, Houndsmill/UK and New York: Pelgrave, 247-262.

Frydman, R. and Goldberg, M. D. (2007): Imperfect Knowledge Economics: Exchange Rates and Risk, Princeton, NJ.: Princeton University Press.

Greenspan, A. (2008): We will never have a perfect model of risk. Financial Times, 16, March.

Hayek, F. A. (1941): Pure Theory of Capital, London: MacMillan.

Hayek, F. A. (1978): The Constitution of Liberty, Chicago: University of Chicago Press.

Hume, D. (1752): Essays, Morals, Political and Literary, Edinburgh.

Keynes, J. M. (1930): The Great Slump of 1930, London: The Nation and Athenaeum, Dec. 20, 27.

Keynes, J. M. (1936/1965): (General Theory of Employment, Interest and Money), A kamat, a foglalkoztatás és a pénz általános elmélete, Budapest: Közgazdasági és Jogi Könyvkiadó.

Kornai, J. (1971): Anti-equilibrium, Budapest: Közgazdasági és Jogi Könyvkiadó.

Krugman, P. (2009): How Did Economists Get It So Wrong? The New York Times, September 2.

Krugman, P. (2009/a): Mathematics and Economics, The New York Times, September 11.

Kydland, F. E. - Prescott, E. C. (1982): Time to Build and Aggregate Fluctuations, Econometrica, vol. 50, $1345-1370$.

Lintner, J. (1965): The Valuation of Risky Assets and the Selection of Risky Investments in Stock Portfolios and Capital Budgets, Review of Economic Studies, 47, 13-37.

Locke, J. (1692): Some Considerations of the Consequences of the Lowering of Intererst and Raising the Value of Money, mimeo, Oxford.

Lucas, R. E. Jr. (1975): An Equilibrium Model of the Business Cycle, Journal of Political Economy, Vol. 83. $326-334$.

Lucas, R. E. Jr. (1976): Economic policy evaluation: a critique. In: Brunner, K. and A. H. Meltzer, eds., The Phillips Curve and the Labor Market, Amsterdam: North-Holland Publ. Co.

Lucas, R. E. Jr. (1977): Understanding Business Cycles. In: Brunner, K. and A. H. Meltzer, eds., Stabilization of the Domestic and International Economy, Vol. 5. Carnegie-Rochester Series on Public Economics.

Mankiw, N. G (2003): Makroökonómia, Osiris Kiadó, Budapest.

Markowitz, H. (1952): Portfolio Selection, Journal of Finance, vol. 7. March, 77-91.

Móczár József (2006): Arrow-Debreu modell és a Kornai-kritika 30 év után, Közgazdasági Szemle, 2. szám, 171-199.

Móczár József (2008): Fejezetek a modern közgazdaság-tudományból, Budapest: Akadémiai Kiadó.

Móczár József (2008): Közgazdaságtan vagy közgazdaság-tudomány? A XX. század legfontosabb eredményei. I. rész, Competito, VII. évfolyam, 2. szám, 5-34.

Móczár József (2009): Közgazdaságtan vagy közgazdaság-tudomány? A XX. század legfontosabb eredményei. II. rész, Competito, VIII. évfolyam, 1. szám, 76-97.

Shleifer, A. - Vishny, W. R. (1997): The Limits of Arbitrage, The Journal of Finance, Vol. 52, No. 1. 35-55.

Nayyar, D. (2007): Foreword. In: Chang, H. J. ed.: Institutional Change and Economic Development, London: Anthem Press and New York: UNU Press, XVII-XIX.

Selten, R. (1998): Features of empirically observed bounded rationality, European Economic Review, vol. 42. nos. 2-3. 413-436.

Shafer, W. - Sonnenschein, H. (1982): Market demand and excess demand functions. In Handbook of Mathematical Economics, vol. 2. eds. K. J. Arrow - M. D. Intriligator, Amsterdam: North-Holland, 671-693.

Sharpe, W. F. (1964): Capital Asset Pricing: A Theory of Market Equilibrium Under Conditions of Risk, The Journal of Finance, 19, 425-442.

Simon, H. (1957): Models of Man: Social and Rational, New York: John Wiley and Sons.

Stiglitz, J. E. (2002): Globalization and Its Discontents, London: Allen Lane.

Summers, L. (1985): On Economics and Finance, The Journal of Finance, vol. 40, no. 3, 633-635.

Weintraub, E. R. (2002): How Economics Became Mathematical Science, Durham, NC.: Duke University Press.

Zalai, E. (2000): Matematikai közgazdaságtan, Budapest: Közgazdasági és Jogi Könyvkiadó. 